\title{
Development of Wellhead Safety Zone Criteria for Underground Gas Storage Facilities
}

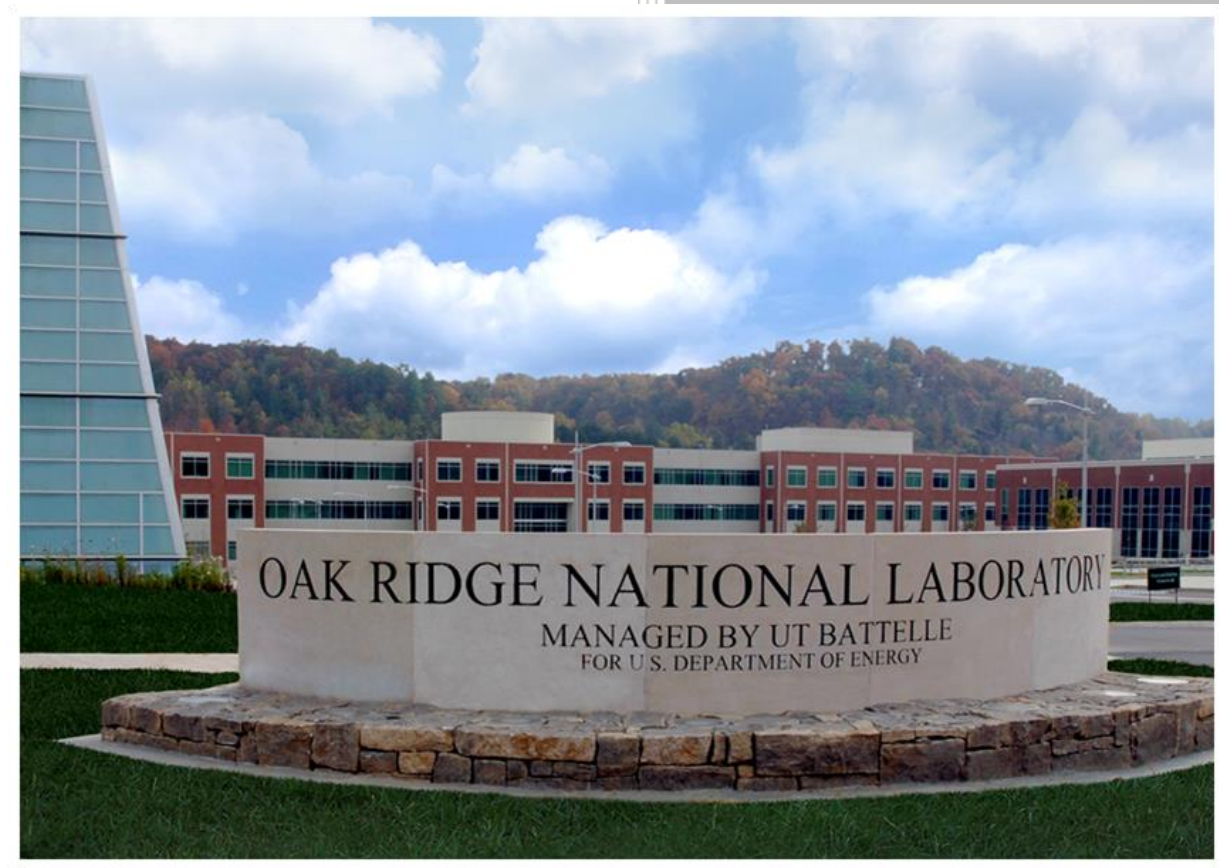

Approved for public release. Distribution is unlimited.

C. David Sulfredge

Simon D. Rose

August 2018 


\title{
DOCUMENT AVAILABILITY
}

Reports produced after January 1, 1996, are generally available free via US Department of Energy (DOE) SciTech Connect.

Website www.osti.gov

Reports produced before January 1, 1996, may be purchased by members of the public from the following source:

\author{
National Technical Information Service \\ 5285 Port Royal Road \\ Springfield, VA 22161 \\ Telephone 703-605-6000 (1-800-553-6847) \\ TDD 703-487-4639 \\ Fax 703-605-6900 \\ E-mail info@ntis.gov \\ Website http://classic.ntis.gov/
}

Reports are available to DOE employees, DOE contractors, Energy Technology Data Exchange representatives, and International Nuclear Information System representatives from the following source:

Office of Scientific and Technical Information

PO Box 62

Oak Ridge, TN 37831

Telephone 865-576-8401

Fax 865-576-5728

E-mail reports@osti.gov

Website http://www.osti.gov/contact.html

This report was prepared as an account of work sponsored by an agency of the United States Government. Neither the United States Government nor any agency thereof, nor any of their employees, makes any warranty, express or implied, or assumes any legal liability or responsibility for the accuracy, completeness, or usefulness of any information, apparatus, product, or process disclosed, or represents that its use would not infringe privately owned rights. Reference herein to any specific commercial product, process, or service by trade name, trademark, manufacturer, or otherwise, does not necessarily constitute or imply its endorsement, recommendation, or favoring by the United States Government or any agency thereof. The views and opinions of authors expressed herein do not necessarily state or reflect those of the United States Government or any agency thereof. 
Computational Sciences and Engineering Division

Energy and Transportation Science Division

\title{
Development of Wellhead Safety Zone Criteria for Underground
} Gas Storage Facilities

C. David Sulfredge

Simon D. Rose

Date Published: August 2018

\author{
Prepared by \\ OAK RIDGE NATIONAL LABORATORY \\ Oak Ridge, TN 37831-6283 \\ managed by \\ UT-BATTELLE, LLC \\ for the \\ US DEPARTMENT OF ENERGY \\ under contract DE-AC05-00OR22725
}




\section{CONTENTS}

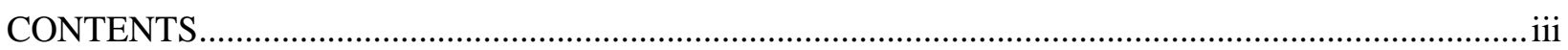

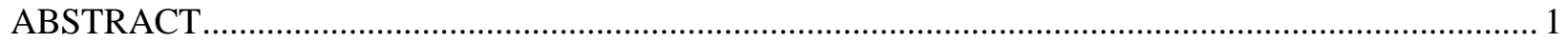

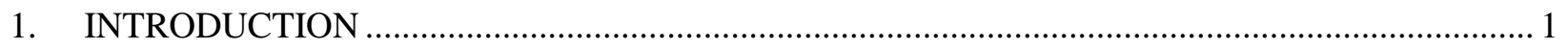

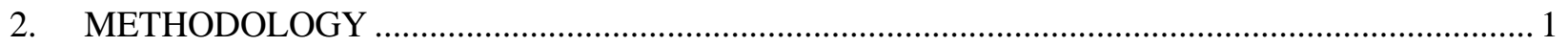

2.1 GAS DYNAMICS OF RESERVOIR DISCHARGE ................................................ 1

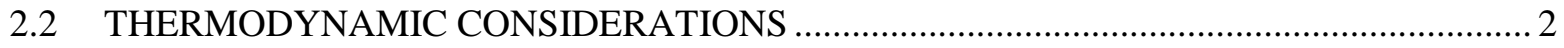

2.3 SOLUTION FOR GAS DISCHARGE .................................................................... 3

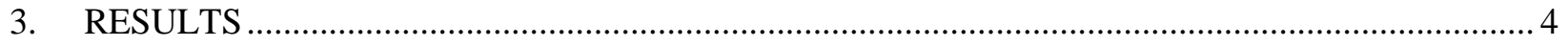

3.1 BOUNDING CASES FOR GAS STORAGE FACILITIES ......................................4

3.2 COMPARISON WITH MOSS BLUFF INCIDENT ..................................................5

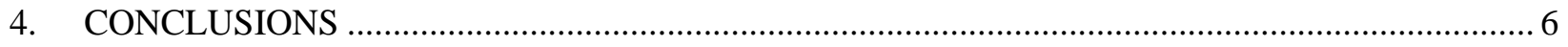

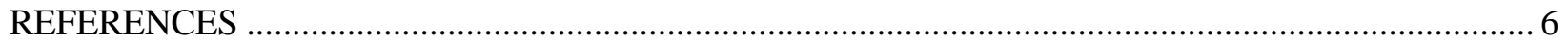




\begin{abstract}
Underground natural gas storage facilities are a vital part of the U. S. national infrastructure. However, the concept of hazard zones from fires and explosions at these facilities is not nearly as well defined as it is for natural gas transmission pipelines. This report will take a well-established criterion for pipeline hazard zones (the Pipeline Impact Radius or PIR) and adapt it to underground gas storage facilities. The new safety area predicted for an underground gas storage facility will be called the Wellhead Safety Zone or WSZ. Comparisons will be made between the resulting WSZ formula and the observed damage zone from known accidents at gas storage facilities.
\end{abstract}

\title{
1. INTRODUCTION
}

A widely accepted criterion for the potential hazard zone due to fire following a natural gas pipeline break was developed by Mark J. Stephens of the Gas Research Institute [1]. Stephens expressed his hazard zone in terms of the area that would be subjected to an average radiant heat flux greater than $5000 \mathrm{Btu} / \mathrm{hr}-\mathrm{ft}^{2}$ over the first 30 seconds of the fire. Gas ignition was assumed to take place simultaneously with the pipeline rupture. This set of criteria gives rise to a Pipeline Impact Radius (PIR) defined by the formula:

$$
\mathrm{PIR}=0.685^{*}\left(\mathrm{Pd}^{2}\right)^{1 / 2}
$$

where $\mathrm{P}$ is the absolute pipeline pressure in psia, $\mathrm{d}$ is the line diameter in inches, and the PIR is expressed in feet [1]. Stephens assumed a double-ended break of the pipeline, with gas discharging from both ends. $\mathrm{He}$ also assumed a combustion efficiency of 0.35 for the gas and that average gas flow over the first 30 seconds of the blowdown would be only $33 \%$ of the initial instantaneous flow rate [1].

As part of the effort at Oak Ridge National Laboratory (ORNL) to establish a wellhead safety zone for natural gas storage facilities, adjustments will be made to Stephens' assumptions to adapt his PIR formula to this new set of facility conditions.

\section{METHODOLOGY}

A key aspect of analyzing natural gas storage facility releases is developing a model for the gas discharge rate as a function of time. The solution is a blowdown calculation using a specified reservoir volume and adiabatic expansion of the gas through the orifice with the flow rate given by the expression for choked flow. The result gives closed-form expressions for pressure and temperature as functions of time and mass loss rate through the orifice as a function of time.

\subsection{GAS DYNAMICS OF RESERVOIR DISCHARGE}

According to the work of Stephens [1], the choked discharge of gas from a reservoir has a mass flow rate $\mathrm{m}_{\mathrm{dot}}$ given by:

$$
\mathrm{m}_{\mathrm{dot}}=\mathrm{C}_{\mathrm{D}} \mathrm{P} \mathrm{A}_{\mathrm{c}}\left[(\gamma / \mathrm{RT})(2 /(\gamma+1))^{(\gamma+1) /(\gamma-1)}\right]^{1 / 2},
$$

where $\mathrm{P}$ is the absolute reservoir pressure, $\mathrm{T}$ is the absolute temperature, $\gamma$ is the ratio of specific heats for the gas, and $\mathrm{R}$ is the ideal gas constant for the gas involved. In Eq. (2) $\mathrm{A}_{\mathrm{c}}$ is the cross-sectional area of the opening and $C_{D}$ is an empirical factor called the discharge coefficient $(\approx 0.62)$, which accounts for the fact that the outflow stream tends to narrow and not make full use of the entire cross-sectional area of the opening. The minimum flow area is called the "vena contracta." 


\subsection{THERMODYNAMIC CONSIDERATIONS}

Equation (2) shows that the discharge mass flow rate depends on both the reservoir pressure and reservoir temperature, which are themselves changing throughout the transient blowdown. The blowdown process is relatively rapid and there is not much time for heat transfer between the reservoir walls and the gas. Thus, it is reasonable to assume an adiabatic condition for the gas, and a relationship between the reservoir gas temperature and pressure can be obtained by applying the energy equation. Under adiabatic conditions, the energy equation requires that the time rate of change for the internal energy of the gas in the reservoir plus the rate of enthalpy transport by the escaping gas equals 0 :

$$
\mathrm{d} / \mathrm{dt}(\mathrm{mu})+\mathrm{m}_{\mathrm{dot}} \mathrm{h}=0,
$$

where $\mathrm{m}$ is the mass of gas in the reservoir, $\mathrm{u}$ is the internal energy of the gas, and $\mathrm{h}=\mathrm{u}+\mathrm{Pv}$ is the enthalpy [2].

If one expands the first term in Eq. (3) and notes that $m_{\mathrm{dot}}=-\mathrm{dm} / \mathrm{dt}$ from the conservation of mass, then

$$
\mathrm{m}(\mathrm{du} / \mathrm{dt})+\mathrm{u}(\mathrm{dm} / \mathrm{dt})-\mathrm{h}(\mathrm{dm} / \mathrm{dt})=0
$$

Since $h=u+P v$ and $P v=R T$ from the ideal gas law, it follows that

$$
\mathrm{m}(\mathrm{du} / \mathrm{dt})=\mathrm{RT}(\mathrm{dm} / \mathrm{dt})
$$

Now the internal energy of an ideal gas can be expressed in terms of the gas temperature as $u=c_{v} T$ where $\mathrm{c}_{\mathrm{v}}$ is the specific heat of the gas at constant volume

$$
\mathrm{m} \mathrm{c}_{\mathrm{v}}(\mathrm{dT} / \mathrm{dt})=\mathrm{RT}(\mathrm{dm} / \mathrm{dt}) \text {. }
$$

One can simplify Eq. (6) using the chain rule by noting that $\mathrm{dT} / \mathrm{dt}=(\mathrm{dT} / \mathrm{dm})(\mathrm{dm} / \mathrm{dt})$ so that

$$
\mathrm{mc}_{\mathrm{v}}(\mathrm{dT} / \mathrm{dm})=\mathrm{RT} \text {. }
$$

Furthermore $\mathrm{R} / \mathrm{c}_{\mathrm{v}}=\gamma-1$, so Eq. (7) can be separated and expressed as:

$$
\mathrm{dT} / \mathrm{T}=(\mathrm{dm} / \mathrm{m})(\gamma-1) .
$$

Integrating Eq. (8) from the initial reservoir temperature and gas mass $\left(\mathrm{T}_{\mathrm{i}}\right.$ and $\left.\mathrm{m}_{\mathrm{i}}\right)$ to some later condition yields:

$$
\mathrm{T} / \mathrm{T}_{\mathrm{i}}=\left(\mathrm{m} / \mathrm{m}_{\mathrm{i}}\right)^{\gamma-1}
$$

It is possible to convert Eq. (9) into a relationship between pressure and temperature by recognizing that the gas specific volumes must be in the inverse ratio of the reservoir gas masses so that

$$
\mathrm{T} / \mathrm{T}_{\mathrm{i}}=\left(\mathrm{v}_{\mathrm{i}} / \mathrm{v}\right)^{\gamma-1}
$$

and noting that $\mathrm{Pv}=\mathrm{RT}$ from the ideal gas law. Carrying out the calculation yields:

$$
\mathrm{T} / \mathrm{T}_{\mathrm{i}}=\left(\mathrm{P} / \mathrm{P}_{\mathrm{i}}\right)^{(\gamma-1) / \gamma}
$$


which matches a standard relationship for the temperature and pressure of an ideal gas undergoing an isentropic process [2].

\subsection{SOLUTION FOR GAS DISCHARGE}

Returning to Eq. (2), one can replace $\mathrm{m}_{\mathrm{dot}}$ by $-\mathrm{dm} / \mathrm{dt}$. If the reservoir consists of a volume $\mathrm{V}$ and the rupture is a guillotine break with the same cross-sectional area as the wellhead pipe

$$
\mathrm{m}=\mathrm{PV} /(\mathrm{RT})
$$

and

$$
(\mathrm{d} / \mathrm{dt})[\mathrm{P} \mathrm{V} /(\mathrm{RT})]=-\mathrm{C}_{\mathrm{D}} \mathrm{P} \mathrm{A}_{\mathrm{c}}\left[(\gamma / \mathrm{RT})(2 /(\gamma+1))^{(\gamma+1) /(\gamma-1)}\right]^{1 / 2}
$$

Equation (11) can be used to eliminate $\mathrm{T}$ in terms of $\mathrm{P}$ in Eq. (13) to obtain a single differential equation for the reservoir pressure as a function of time,

$$
\mathrm{P}_{\mathrm{i}}^{(\gamma-1) /(2 \gamma)}\left(\mathrm{L} \mathrm{V} / \mathrm{T}_{\mathrm{i}}^{1 / 2}\right)(1 / \gamma) \mathrm{P}^{(1 / \gamma)-1}(\mathrm{dP} / \mathrm{dt})=-\mathrm{C}_{\mathrm{D}} \mathrm{A}_{\mathrm{c}}\left[\gamma \mathrm{R}(2 /(\gamma+1))^{(\gamma+1) /(\gamma-1)}\right]^{1 / 2} \mathrm{P}^{(\gamma+1) /(2 \gamma)} .
$$

Defining the constant $\zeta$ as

$$
\zeta=-\mathrm{C}_{\mathrm{D}} \mathrm{A}_{\mathrm{c}}\left[\gamma \mathrm{R}(2 /(\gamma+1))^{(\gamma+1) /(\gamma-1)}\right]^{1 / 2} \mathrm{P}_{\mathrm{i}}^{-(\gamma-1) /(2 \gamma)} \mathrm{T}_{\mathrm{i}}^{1 / 2} / \mathrm{V},
$$

and separating variables in Eq. (15) gives

$$
(1 / \gamma) \mathrm{P}^{(1-3 \gamma) /(2 \gamma)} \mathrm{dP}=\zeta \mathrm{dt}
$$

which can be integrated between pressure $P_{i}$ at time $t=0$ and pressure $P$ at some later time.

The resulting equation is:

$$
\mathrm{P}(\mathrm{t})=\left[((1-\gamma) / 2) \zeta \mathrm{t}+\mathrm{P}^{(1-\gamma) /(2 \gamma)}\right]^{2 \gamma /(1-\gamma)} .
$$

Once the pressure at time t has been determined from Eq. (17), the temperature for that time is obtained from Eq. (11) and the corresponding discharge mass flow rate is then obtained from Eq. (2). The calculated flow rate will remain valid as long as the reservoir pressure is high enough to cause choked flow at the exit plane, which requires [3]

$$
\mathrm{P}>\mathrm{P}_{\mathrm{atm}}[(\gamma+1) / 2]^{\gamma /(\gamma-1)} .
$$

Using $\gamma=1.32$ for natural gas and $\mathrm{P}_{\mathrm{atm}}=14.7$ psi for the absolute atmospheric pressure, Eq. (18) indicates that choked flow will occur for reservoir pressures of $\mathrm{P}>27.1 \mathrm{psi}$.

The preceding model has been coded as an Excel spreadsheet for determining the mass flow rates of escaping gas from a broken gas storage wellhead as a function of time following the break.

The instantaneous hazard radius, $r$, for a particular heat flux level from the natural gas fire can be found from the instantaneous gas discharge rate $m_{\text {dot }}$ using the formula:

$$
\mathrm{r}=\left[0.2 \eta \mathrm{H}_{\mathrm{c}} \mathrm{m}_{\mathrm{dot}} /(4 \pi \mathrm{I})\right]^{1 / 2},
$$


where $\eta$ is the gas combustion efficiency factor, $\mathrm{H}_{\mathrm{c}}$ is the heat of combustion for the gas (about 50,000 $\mathrm{kJ} / \mathrm{kg}$ for methane), and I is the heat flux level of interest.

\section{RESULTS}

Equation (19) has been used to track the radius associated with a particular heat flux level in the Excel spreadsheet at each stage of the gas storage wellhead blowdown.

\subsection{BOUNDING CASES FOR GAS STORAGE FACILITIES}

Some results are collected below for the $5000 \mathrm{Btu} / \mathrm{hr}^{-\mathrm{ft}^{2}}$ radius as a function of time for a reasonable bounding range of blowdown cases: a very large, high-pressure design of gas storage facility [22.2 billion cubic feet (BCF) of gas at 3600 psi pressure and a 19.25 inch wellhead diameter] and a much smaller facility (0.83 BCF at 2200 psi with a 7 inch wellhead).

\section{Large Gas Storage Facility Case}

Initial pressure $=3600 \mathrm{psi}$

Reservoir $\mathrm{V}=22.2 \mathrm{BCF}$

Well $\mathrm{D}=19.25$ inches

$\mathrm{PIR}=0.685^{*}\left(\mathrm{Pd}^{2}\right)^{1 / 2}=791 \mathrm{ft}$

Time (hrs)

0

0.5

1

12

24

48

\section{Small Gas Storage Facility Case}

Initial pressure $=2200 \mathrm{psi}$

Reservoir $\mathrm{V}=0.83 \mathrm{BCF}$

Well $\mathrm{D}=7$ inches

$\mathrm{PIR}=0.685^{*}\left(\mathrm{Pd}^{2}\right)^{1 / 2}=224.9 \mathrm{ft}$

Time (hrs)

0

0.25

0.5

1

12

24
$5000 \mathrm{Btu} / \mathrm{hr}^{-\mathrm{ft}^{2}}$ radius from fire

$\begin{array}{crr}\text { burn } \eta=0.35 & \text { burn } \eta=1.0 & \text { burn } \eta=0.5 \\ 974.7 \mathrm{ft} & 1647.6 \mathrm{ft} & 1165.0 \mathrm{ft} \\ 963.0 \mathrm{ft} & 1627.7 \mathrm{ft} & 1151.0 \mathrm{ft} \\ 951.4 \mathrm{ft} & 1608.1 \mathrm{ft} & 1137.1 \mathrm{ft} \\ 736.0 \mathrm{ft} & 1244.1 \mathrm{ft} & 879.7 \mathrm{ft} \\ 566.7 \mathrm{ft} & 957.9 \mathrm{ft} & 677.3 \mathrm{ft} \\ 352.8 \mathrm{ft} & 596.3 \mathrm{ft} & 421.6 \mathrm{ft}\end{array}$

$5000 \mathrm{Btu} / \mathrm{hr}^{-\mathrm{ft}^{2}}$ radius from fire

burn $\eta=0.35$
$277.1 \mathrm{ft}$
$273.5 \mathrm{ft}$
$269.9 \mathrm{ft}$
$263.0 \mathrm{ft}$
$154.7 \mathrm{ft}$
$93.4 \mathrm{ft}$

$\begin{array}{cc}\text { burn } \eta=1.0 & \text { burn } \eta=0.5 \\ 468.3 \mathrm{ft} & 331.2 \mathrm{ft} \\ 462.2 \mathrm{ft} & 326.9 \mathrm{ft} \\ 456.2 \mathrm{ft} & 322.6 \mathrm{ft} \\ 444.5 \mathrm{ft} & 314.3 \mathrm{ft} \\ 261.5 \mathrm{ft} & 184.9 \mathrm{ft} \\ 157.9 \mathrm{ft} & 111.6 \mathrm{ft}\end{array}$


In both these cases, blowdown of the gas storage reservoir requires from one to several days to complete. It is important to note that the blowdown for even a small gas storage well is much slower than Stephens found for pipeline break transients [1], and there is little decrease in the initial hazard radius over the first few hours (much less the first 30 seconds as observed by Stephens for pipelines) of the blowdown. Also, the $5000 \mathrm{Btu} / \mathrm{hr}-\mathrm{ft}^{2}$ radius at time $\mathrm{t}=0$ is greater than the Stephens PIR, even when the same burn efficiency of 0.35 is assumed.

There are definitely two things that need to be done to adapt the PIR methodology from a pipeline case to an underground gas storage reservoir. The PIR derivation assumes a double-ended break of the pipeline, with both ends discharging gas. A gas storage well only has a one-sided situation with gas emerging from the reservoir, so this factor of two is not needed. The PIR also applies an averaging factor of 0.33 to the initial flow rate to account for reduction in flow over the first 30 seconds of the blowdown (which is appreciable in a pipeline where the ratio of gas volume to hole size is much less). For an underground reservoir the gas flow decays much slower and, one certainly should not use this factor of 0.33 . Therefore, the true radius from a well rupture where one would have a heat flux of $5000 \mathrm{Btu} / \mathrm{hr}-\mathrm{ft}^{2}$ is given by $\operatorname{PIR} *[(1 / 2) *(1 / 0.33)]^{1 / 2}=\operatorname{PIR}^{*} 1.2309$ if one continues to assume a burn efficiency of $\eta=0.35$.

Applying this factor of 1.2309 to the Stephens PIR values yields $1.2309 *(791$ feet $)=974$ feet for the large high-pressure gas storage case and $1.2309 *(224.9$ feet $)=277$ feet for the smaller low-pressure case. In both of these instances, the adjusted PIR now matches the calculated $5000 \mathrm{Btu} / \mathrm{hr}-\mathrm{ft}^{2}$ radius at time $\mathrm{t}=0$ for an assumed burn efficiency of 0.35 .

\subsection{COMPARISON WITH MOSS BLUFF INCIDENT}

The Moss Bluff, TX accident of August 2004 provides an opportunity to refine the formula further and select an appropriate value for the burn efficiency. Moss Bluff involved blowdown of 5.4 BCF of gas with an initial pressure of $1898 \mathrm{psi}$ and a wellhead diameter of 20 inches. The results of simulating these blowdown conditions with the Excel spreadsheet are shown below:

\section{Moss Bluff parameters}

Initial pressure $=1898 \mathrm{psi}$

Reservoir $\mathrm{V}=5.4 \mathrm{BCF}$

Well $\mathrm{D}=20$ inches

$\mathrm{PIR}=0.685^{*}\left(\mathrm{Pd}^{2}\right)^{1 / 2}=596.9 \mathrm{ft}$

Time (hrs)
0
0.25
0.5
1
12
24
48

$\begin{array}{ccc}5000 \mathrm{Btu} / \mathrm{hr}^{-\mathrm{ft}^{2}} \text { radius from fire } & \\ \text { burn } \eta=0.35 & \text { burn } \eta=1.0 & \text { burn } \eta=0.5 \\ 735.3 \mathrm{ft} & 1242.9 \mathrm{ft} & 878.9 \mathrm{ft} \\ 725.0 \mathrm{ft} & 1225.4 \mathrm{ft} & 866.5 \mathrm{ft} \\ 714.8 \mathrm{ft} & 1208.2 \mathrm{ft} & 854.3 \mathrm{ft} \\ 695.0 \mathrm{ft} & 1174.7 \mathrm{ft} & 830.6 \mathrm{ft} \\ 392.7 \mathrm{ft} & 663.8 \mathrm{ft} & 469.4 \mathrm{ft} \\ 229.4 \mathrm{ft} & 387.8 \mathrm{ft} & 274.2 \mathrm{ft} \\ 94.4 \mathrm{ft} & 159.5 \mathrm{ft} & 112.8 \mathrm{ft}\end{array}$

Moss Bluff took several days to blow down the 5.4 BCF of gas, so the spreadsheet calculation is reasonably consistent with this timeline. According to the best available information, the burn radius at Moss Bluff 
was 840 feet. This is somewhat greater than the calculated Moss Bluff PIR of 596.9 feet, indicating some adjustments to the pipeline PIR formula are necessary.

\section{CONCLUSIONS}

Correcting for the double ended issue and the slower nature of a reservoir blowdown compared to a pipe break would give a new PIR of 1.2309*596.9 feet $=735$ feet at Moss Bluff, as can be seen in the tabulated blowdown model results with $\eta=0.35$, which is still too small compared to the observed burn radius of 840 feet.

The other possible change to the PIR concerns increasing the assumed burn efficiency of $\eta=0.35$. As shown from the Moss Bluff tables above, assuming $\eta=1.0$ would indicate a radius of $1242.9 \mathrm{ft}$ under Moss Bluff conditions, which is too big. The exact $\eta$ needed to match the observed $840 \mathrm{ft}$ radius is actually $\eta=$ 0.46 . Given the uncertainties involved, it seems reasonable to use $\eta=0.50$ for simplicity and to include a small amount of conservatism in the formula. The new adjusted PIR for a gas storage facility will be referred to as a Wellhead Safety Zone (or WSZ).

This means the new WSZ formula would be given by:

$$
\begin{aligned}
\mathrm{WSZ}= & {\left[0.685 * 1.2309 *(0.50 / 0.35)^{1 / 2}\right] *\left(\mathrm{P}^{*} \mathrm{~d}^{2}\right)^{1 / 2} } \\
& \mathrm{WSZ}=1.008 *\left(\mathrm{P}^{*} \mathrm{~d}^{2}\right)^{1 / 2} .
\end{aligned}
$$

Thus, the new coefficient in the WSZ formula is 1.008 instead of the 0.685 PIR value found in Stephens' Gas Research Institute report for pipeline breaks (an increase of 47\%), and the WSZ for Moss Bluff would be 878 feet, which is a very good correspondence with the 840 feet burn radius observed at Moss Bluff.

The new WSZ formula will also need to be tested against any other fires at gas storage facilities (such as the accident at Dominion, PA) for which data on the damage radius can be obtained.

\section{REFERENCES}

1. M. J. Stephens, A Model for Sizing High Consequence Areas Associated with Natural Gas Pipelines, Topical Report prepared for the Gas Research Institute by C-FER Technologies, GRI-00/0189, October 2000.

2. G. J. Van Wylen and R. E. Sonntag, Fundamentals of Classical Thermodynamics, $3^{\text {rd }}$ Ed., John Wiley \& Sons, Inc., New York, NY, 1985.

3. J. E. A. John, Gas Dynamics, $2^{\text {nd }}$ Ed., Allyn and Bacon, Boston, 1984. 
ORNL/TM-2018/945

\section{INTERNAL DISTRIBUTION}

1. S. D. Rose

2. C. D. Sulfredge

\section{EXTERNAL DISTRIBUTION}

3. A. P. Franks, AFEnergy, LLC, 11757 W. Ken Caryl Ave., \#F273, Littleton, CO 80127

4. J. Pfeifle, Pipeline and Hazardous Material Safety Administration, 820 Bear Tavern Rd., Suite 103, West Trenton, NJ 08628 